\title{
WHAT ECONOMIC AND SOCIAL FACTORS AFFECT GDP PER CAPITA? A STUDY ON 40 COUNTRIES
}

\author{
Cenap Ilter \\ California State University Dominguez Hills, USA
}

\begin{abstract}
This paper explores the social and economic factors that affect GDP per capita as a gauge of economic development for a sample of forty countries. The whole sample is subjected to regression analysis as GDP per capita is being the dependent variable and the rest of the factors are being the independent variables. Regression analysis showed that of the eleven independent variables, population, GDP, transparency score and compulsory education are the four factors that affect GDP per capita the most.
\end{abstract}

Key words: GDP per capita, GDP, transparency, population, compulsory education.

Jel code: $O 01$

\section{INTRODUCTION}

Economic discrepancies among the countries has been a subject to be explored by the author. There are approximately 200 countries in the World but economically they are dispersed and have economic gaps among themselves. Over the past few decades we have been hearing the term "globalization." Globalization is leading to a smaller World in the sense that the trade barriers are being lowered, and trade becomes easier to handle as technology advances and carriers become faster.

With regards to the quality of human life, education, per capita income, we have observed improvements on some parts of the World but it has not been a wide spread phenomenon when you look at the global picture. World development as a whole has not been in tandem on all parts of the World. This paper is evaluating these issues for forty countries. It is measuring the effects of transparency on the economic development as it is one of the independent variables in the equation. It is the governments responsibility in general to increase the quality of life of its own citizens and for this very basic reason we have borders and visas and limitation of travel for people on the World despite the fact that globalization has been in effect for many years already. Besides, economic crises are being a hurdle for globalization to spread out because of their contagious nature. The interdependency within the countries is so large that economic crises of one can lead a chain effect on the others. Of the EU's 27 (presently 28) Member States, Poland is the only one that did not experience a single year of recession during the critical period 2007-11. Eight countries - Estonia, France, Italy, Portugal, Romania, Spain, Sweden and the United Kingdom - suffered a so-called double dip, with two years of recession within that period. Greece, Ireland and Latvia experienced "multiple dips", while the rest of the EU countries had at least one year of GDP contraction (in 2009) (Tridico, 2013). The crux of the paper is the GDP, GDP per capita and the analysis of possible factors affecting the GDP and GDP per capita growth. As it will be explained in more detail below, GDP is the abbreviation of Gross Domestic Product which is the total of all goods and services produced within a year in an economy. GDP per capita is the total GDP divided by the population of the country, a development indicator of a country vis a vis others. I.e. developed countries have a GDP per capita between USD30- 50,000 or above per year whereas developing countries have between USD10-30,000. Factors affecting GDP per capita are GDP itself, population mass of a country, its land size, i.e. Russia has 17 million square mile land size-the greatest country on the World. We will analyze how effective this land size on the GDP per capita for all the countries in our sample. I.e. China has the greatest GDP on the Earth but divided by its population its down on the road on the scale based GDP per capita. Transparency score and transparency ranking are two more factors that might affect the GDP per capital. These two factors are issued by Transparency International Organization every year. Transparency and economic growth are in sync but again we will analyze how affective they or GDP per capita. GDP growth rate is another possible factor affecting the GDP per capita. I.e. GDP measure of the current year 
is divided by the GDP measure of the previous year adjusted for the inflation. Inflation is itself is another factor to be tested if it has any effect on GDP per capita. Youth unemployment, population below poverty are two more factors to be analyzed. It seems that as increase your production more youth can be employed. Is it true or are there other factors affecting it. It might be the case that as GDP increases in the country more youth seek further education and youth unemployment might still increase. Population below poverty line sounds to be eliminated as GDP per capita grows. Is it really the case or each country has its own definition of poverty line and consequently it is hard to find a correlation? Compulsory education and type of government either being democrat or monarchic are the last two factors that will be measured for their effectiveness on GDP per capita. Compulsory education might effective on GDP per capita however is the country supplying equal education opportunities for its citizens or are there regional discrepancies? Are the governments providing equal opportunities for its male and female youth equally? Democracies are a widely spread notion among highly developed countries. This might lead us to the expectation that GDP per capita is high for all democratic countries. But it might not be true. Qatar is rich for GDP per capita, is it also democratic? Not really. The reader will find answers to all these questions in the remaining part of the paper.

In this paper I will be analyzing the effects of various independent variables on GDP per capita for 40 countries on the World that make up the 64\% of the total World`s economy in 2014. The paper is organized as follows: Research question part explains the independent variables, their measurement units and their possible maximum and minimum scores (if there is any) that would affect GDP per capita. Literature review part explains each individual independent variable`s effect on the dependent variable (GDP per capita) and compares it with the findings of similar articles that are comparing the same ingredients` effects on GDP per capita or GDP growth. It also explains that if the correlation between an independent variable and the dependent variable is positive one or a negative one and if it is significant or insignificant. Methodology and definition of variables part explains where I have obtained the data from and how I have processed it statistically. Discussion part explains all statistical results of the analysis. It explains R square, $\mathrm{F}$, $\mathrm{t}$ and $\mathrm{P}$ values, their ranges and what correlation exists between each independent variable and the dependent one and weather this correlation is a significant one or an insignificant one and highlights the significant ones. Research limitations, future research opportunities and practical implications for countries part explains what are the limitations of the paper, what other future studies can be done, what other independent variables can be used, what other comparisons can be made. How countries can benefit from GDP growth, what incentives can they use to increase their GDP and evenly distribute it over their population and minimize income inequality. Finally, conclusion part explains what are the independent variables that affected the GDP per capita most significantly and what are the implications of this on practical grounds.

\section{RESEARCH QUESTION}

There are numerous factors that affect the economic development discrepancies among the nations. This paper is not suggesting a comprehensive answer to the reasons that are leading to the economic discrepancies among the nations. The following variables have been analyzed in the paper: population (in millions), land area (as kilometer square), transparency score (from 0 to 100, 100 being the most transparent), transparency ranking (from 1 to 175, 1 being the most transparent), Gross Domestic Product (GDP) in billion United States Dollar (USD), GDP per capita in Purchasing Power Parity (PPP) in USD, GDP growth rate, inflation (on consumer price index), youth unemployment, population below poverty line, compulsory education years (both for men and women in average), type of government-either being democratic or non-democratic.

Taking into account that GDP per capita is a major indicator of development, the research question of this study is "What are the effects of these variables on GDP per capita?" It is expected that each variable`s effect is different on GDP per capita. The per capita GDP is useful when comparing one country to another because it shows the relative performance of one country over the other(s). A rise in per capita GDP signals growth in the economy and connotes that the country is progressing and coping with its challenges like unemployment, industrialization, export and import growth, etc. Two of the independent variables are the transparency and transparency ranking of the country. Presently, multinational companies prefer to invest in those countries where there is high transparency. Transparency may not be 
the sole criterion but it is one of the important criteria on which multinational companies prefer to invest. Transparency among the other things implies free judiciary, freedom of speech, freedom of press, balance of powers, and a low level of corruption.

This study is a study that tries 11 independent factors in determining how effective they are in changing the GDP per capita. Previous studies (e.g. Chughtai. Malik and Aftab 2015 used 3, Hussain and Haque 2016 used 5, Upreti used 8, Hussain, Sabir and Kashif 2016 used 3, Agalega and Antwi 2013 used 2 independent variables) used not as much independent variables as this one. This paper tries 11 independent variables and analyzes which ones have meaningful correlations with GDP per capita which I balieve emphasizes the reason of its being an important research paper.

According to the economist Daron Acemoglu and the political scientist James Robinson, economic development hinges on a single factor: a country's political institutions. More specifically, as they explain in their new book, Why Nations Fail, it depends on the existence of "inclusive" political institutions, defined as pluralistic systems that protect individual rights. These, in turn, give rise to inclusive economic institutions, which secure private property and encourage entrepreneurship. The long-term result is higher incomes and improved human welfare (Sachs, 2012).

\section{LITERATURE REVIEW}

There are many publications issued on GDP per capita and its relationships with population, land area, transparency score, transparency ranking, GDP, GDP growth rate, inflation, youth unemployment rate, population below poverty line, compulsory education period and type of government either democratic or non-democratic. The publications have been scanned in a way to see if the findings of this paper are in conformity with the extant literature in this field. GDP per capita as being the dependent variable in the equation and its relationship with the 11 independent variables are analyzed below to see if there are supporting studies, articles in this field:

GDP per capita and population: Under normal circumstances one can expect that ceteris paribus the higher the population the lower the GDP per capita. This quantitative analysis suggests that, because the Seoul Metropolitan Area (SMA) is oversized from both national and regional economic perspectives, higher population concentration results in lower economic growth (Kim, Hewings, Nam 2014). It is not clear that the UK can develop a growth model in the foreseeable future which functions without strong population growth. If a future Conservative government were more successful in curbing immigration, and therefore population growth, an alternative economic strategy supporting capital-intense industries may be required to sustain economic growth (Barry 2014). The findings of this paper is in conformity with higher population`s leading to lower GDP per capita. This finding is quite expected that ceteris paribus population being the denominator of the formula, the higher the population is the lower the GDP per capita will be.

GDP per capita and land area: One might think that the land mass of a country enables that country to produce more GDP that the others. Is this a true hypothesis? The studies show otherwise. The relationship between the land size and the GDP per capita, the findings on this paper conclude that the relationship between the two variables is weak that means land is not a determining factor in obtaining a higher GDP per capita even though at the outset it might seem that it is a determining factor as more land means more resources. This shows us that there is something more important than size. After all, if size were the most important factor, Russia would be the most productive country in the world, and Algeria and Congo together would be producing more than the EU, which is hardly the case (Hahn, 2014). In a similar study one of the findings is as follows: The correlation coefficient between urban per capita GDP and city size was similarly low, less than 0.1 , indicating that city size was not the determining factor of per capita income (Zhang,Yang and Huo 2016).

GDP per capita and transparency score: One might expect that transparency is important in economic development since all developed countries are mostly on the Western semi sphere and governed by democracies. And one can further expects that democracies have transparent governance systems. The objective of this study is to test the hypothesis that there is a strong negative impact of corruption on the GDP per capita. Three tests were conducted, the pool OLS, The Fixed Effect and the Random effect estimations. The main result of this study is that all three tests had shown strong statistically significant 
negative impact of corruption on the GDP per capita (Mustapha, 2014). In another study the authors conclude that: First, corruption can reduce growth by increasing public investment while reducing its productivity. This finding is consistent with typical reduced-form cross-country growth regressions (Tanzi and Davoodi 1997). In line with above studies` findings this paper also suggests that the higher the transparency score of the country the higher its GDP per capita is.

GDP per capita and transparency ranking: Being in sync with above parameter, this is a similar independent variable one might think that would be effective on GDP per capita. Per conclusions of this study the relationship between transparency ranking and GDP per capita is positive ( $t$ value 0.737 and $p$ value 0.467 ) but not significant. The two variables move in the same direction vis a vis GDP per capita. South Africa's score went up by two, from 42 to 44, and managed to jump five places in the rankings, from 72 to joint 67 (Corruption Watch Annual Report, 2014). In another study at https://tradingeconomics.com/tanzania/corruption-rank: Tanzania is the 116 least corrupt nation out of 175 countries, according to the 2016 (GDP per capita USD2,583.3) Corruption Perceptions Index reported by Transparency International. Corruption Rank in Tanzania averaged 98.37 from 1998 until 2016 (average GDP per capita-calculated by the author in the same period is approximately USD672), reaching an all times high of 126 in 2009 (GDP per capita is USD2028.6) and a record low of 71 in 2002 (GDP per capita is 630). As it is observed above there is a positive correlation between transparency ranking and GDP per capita but we can `t say it is an absolute positive relationship since our statistical sample does not show such a correlation neither does the literature review.

GDP per capita and GDP in billion US dollar: These two variables are positively and significantly related as this study purports. They both are the components of the formula calculating GDP per capita (GDP per capita $=$ GDP/population). So, as expected the higher the GDP is the higher the GDP per capita will be. GDP per person is an informative indicator of welfare across a broad range of countries: the two measures have a correlation of 0.98 . Nevertheless, there are economically important differences between GDP per person and consumption equivalent welfare (Jones and Klenow, 2015). This variable might not have been included in the study since the reader might think that the relationship is obvious, however GDP per capita can't be measured without GDP and population. Therefore both population and GDP have been included in the study to show their correlation with GDP per capita, one being negative (population) and the other being positive (GDP).

GDP per capita and GDP growth: One might expect that the higher the economic growth rate the higher the GDP per capita since growth is an economic catalyst for higher GDP. These two variables have been used in other research papers. The concept of GDP per capita itself is self-explanatory. However, it is noteworthy that we used both GDP per capita and GDP growth in our models to estimate the country's income inequality. This is because we believed that GDP growth and GDP per capita can tell the country's economy from different perspectives (Luan and Zhou 2017). The average growth rate per capita real gross domestic product (GDP) from 1960 to 1985 (denoted GR6085) is not significantly related to the 1960 value of real per capita GDP (GDP60); the correlation is 0.09 (Barro, 1991). According to this study and the previous studies above both variables are positively related however their relationship is not significant. Ceteris paribus, the higher the GDP growth rate the higher the GDP per capita.

GDP per capita and inflation: Inflation means there is more money in circulation than there is good and services produced in an economy. This might imply that inflation triggers production-growth as there are higher prices for goods and serviced sold. Various studies in this respect did not find a direct relationship. The authors suggest that while the results of the paper are important, some caution should be borne in mind. The estimated relationship between inflation and growth does not provide the precise channel through which inflation affects growth, ....... (Gokal and Hanif 2004) We interpret this as evidence that Brazil has experienced permanent inflation shocks. Thus, our results suggest that permanent inflation shocks do not have significant permanent effects on output growth rates (Faria and Carneiro, 2001).This paper suggests that GDP per capita is positively related with inflation but the relationship is not significant.

GDP per capita and youth unemployment: The study of the paper suggests that GDP per capita and youth unemployment relationship is positive but non-significant. It implies that the higher the GDP per capita the higher the youth unemployment even though the relationship is weak. This might be true that as 
per capita income increases the educational years increase i.e. Australia where average compulsory education years is 20 and GDP per capita is $\$ 46,400$ (table 1). For youth, employment growth was negative for emerging economies (EEs) and AEs over this period, but positive and comparatively strong in least developed countries (LDCs), where relatively high population growth rates prevailed (World of Work Report, 2014). Another study for Nigeria suggests that: For Nigeria to benefit from its demographic dividend, developing the entrepreneurial potential of its youth population is an important opportunity for growth (Ajakaiye, Afeikhena, Nabena, Olufunke 2016).

GDP per capita and population below poverty line: This paper suggests that the higher the GDP per capita the lesser the populations below poverty line (t value being -1.397) however the relationship is not significant. In 1820 only a few places in the world achieved economic growth-and only to a rather small extent. The progress of the last 200 years was achieved as economic growth brought higher incomes to more and more people in the world...The correlation suggests that in a society with an average income around 10,000 International Dollar, absolute poverty is abolished (http://ourworldindata.org/data/growth-anddistribution-of-prosperity/world-poverty/). Other studies have similar conclusions: Empirical studies increasingly support the idea that countries which have incorporated population policies and family planning programs in their overall economic development strategies have achieved high and sustained rates of economic growth and that they have also managed significant reductions in poverty (Sinding 2009).

GDP per capita and compulsory education years: This study suggests that there is a positive and significant correlation between GDP per capita and compulsory education years. Similar studies on education and growth support this positive correlation. On average, about half of the economic growth is related to labor income growth at the tertiary level of education. In France, Norway, Switzerland and the United Kingdom, $60 \%$ or more of growth in gross domestic product (GDP) is generated by those who have attained a tertiary education (Education at a Glance 2012). The conclusion from these 'twin studies' is that the average estimates suggested by the figure below, are not very different to those that would be obtained from more sophisticated models that control for ability. In other words, there is robust evidence supporting the causal effect of education on wages (authors note: wages are one part of the GDP calculation) (for more details see Card 1999) (Roser and Ortiz-Ospina 2017).

GDP per capita and government: This study suggests that there is a positive correlation between GDP per capita and government. The positive correlation suggests that GDP per capita is higher if the regime of the government is a democratic one, however since the correlation is a weak one it will not be considered as an independent variable in future studies. Other studies in this respect support this conclusion. The empirical divide as to evidence of both positive, negative and no impact of democracy on per capita GDP growth can come if the appropriate step to control simultaneity bias and possible nonlinearity of the growth are not taken into account. Political instability reduces growth (Qureshi and Ahmed 2012) ..... Democracies do not appear to show a different growth performance than nondemocracies. Also, the occurrence of a government change increases the likelihood of subsequent changes, suggesting that political instability tends to be persistent (Alesina, Ozler, Roubini, Swagel. 1996).

\section{METHODOLOGY AND DEFINITION OF VARIABLES}

The data of the sample of 40 countries have been loaded onto Statistical Package for Social Sciences (SPSS) data sheet and the program has been run to measure the effects of the independent variables on GDP per capita as being the dependent variable and the rest of the following 11 criteria being the independent variables:

- Population (in millions)

- Land area (as kilometer square)

- Transparency score

- Transparency ranking

- Gross Domestic Product (GDP) in billion USD

- GDP per capita in Purchasing Power Parity (PPP)

- GDP growth rate (latest) per annum

- Inflation (on consumer price index) 
- Youth unemployment

- Population below poverty line

- Compulsory education years

- Type of government-either being democratic or non-democratic.

All data above for the sample of 40 countries have been obtained from the following United States Central Intelligence Agency`s (CIA) website: https://www.cia.gov/library/publications/the-world-factbook/ except transparency scores and rankings which have been obtained from Transparency International Organization `s website: http://www.transparency.org/cpi2014/results. It is an international organization based in Berlin fighting against the corruption on the World. They regularly issue transparency score and transparency ranking for 175 countries (corruption perception index-CPI). All data from CIA reflect 2014 year end estimated figures and likewise all data from Transparency International`s website reflect 2014 year results. According to Statistics times` website: http://statisticstimes.com/economy/countries-by-gdp-ppp.php: On the PPP basis, GDP of world in 2014 is estimated at \$108 trillion compare to \$103 trillion in 2013. The sample of 40 countries ' GDP per PPP is USD69,330.8 billion, that means the sample covers all major economies of the world and accounts for approximately 64\% of the World`s total GDP per PPP as at 2014 yearend (list of countries and their GDPs per PPP is given in the appendix).

GDP and GDP per capita are the two major indicators of explaining a country`s economic development level in total and per person in average respectively. Generations of elementary economics students since World War II have come away from Economics 101 having learned, if anything, that GDP is defined as

$\mathrm{GDP}=\mathrm{C}+\mathrm{I}+\mathrm{G}+(\mathrm{X}-\mathrm{M})$

That is, GDP for a given period, usually a year, is the sum of spending for final goods and services by domestic private consumers (C), domestic private investors (I), and domestic governments (G) at all levels, plus foreign purchases of U.S. exports (X) minus Americans' purchases of U.S. imports (M) (Higgs, 2013).

Because exchange rate movements, in general, tend to be more volatile than changes in national price levels, the purchasing power parity approach provides the proper basis for comparing living standards and examining productivity levels over time (Vachris and Thomas, 1999).

Youth unemployment: According to International Labor Organization`s website (http://www.ilo.org/public/english/employment/yen/whatwedo/projects/indicators/2.htm): The unemployment rate is defined as the number of unemployed youth (typically 15-24 years) divided by the youth labor force (employment + unemployment). Population below poverty line: According to CIA World fact book (website given above): National estimates of the percentage of the population falling below the poverty line are based on surveys of sub-groups, with the results weighted by the number of people in each group. Definitions of poverty vary considerably among nations. For example, rich nations generally employ more generous standards of poverty than poor nations. The US Census Bureau`s 2014 estimates are $\$ 12,316$ for a single person under 65 years of age (http://www.census.gov/hhes/www/poverty/data/threshld/index.html), whereas in Turkey it is $\$ 4$ per day (Saatci and Akpinar 2007) that means $\$ 1,440$ per year. Type of government has been defined as democratic and nondemocratic. Democratic countries are defined as the Western Semi-Sphere countries`government regimes with free elections and multiparty system and free institutions like free central banks, free universities, free courts. A system, even defined as a republic has not been construed as democratic like Russia or Libya or Kazakhstan where the opposition (if there is any) has never a chance to win the elections, and all institutions are under government control. Other variables like population, inflation, land area, compulsory education have not been explained since they are self-explanatory. 


\section{DISCUSSION}

The regression analysis covers all above mentioned 12 variables. GDP per capita is being the dependent variable and the rest are being the independent variables. The following table is the result of regression analysis through SPSS: Regression analysis results on the sample of 40 countries.

\section{Table 1}

Model Summary

\begin{tabular}{|c|c|c|c|c|c|}
\hline \multicolumn{5}{|c|}{ Model Summary } & \\
\hline Model & $\mathrm{R}$ & R Square & $\begin{array}{c}\text { Adjusted R } \\
\text { Square }\end{array}$ & $\begin{array}{l}\text { Std. Error of } \\
\text { the Estimate }\end{array}$ & \\
\hline 1 & $0.908^{2}$ & 0.808 & 0.756 & 8731.052 & \\
\hline \multirow{2}{*}{\multicolumn{6}{|c|}{$\begin{array}{l}\text { a.Predictors: (Constant), Government, Inflation-CPI, Youth Unemployment, GDP in bn } \$ \text { PPP, } \\
\text { Compulsory education-years, GDP growth-latest, Land area sqkm, Population below poverty line, }\end{array}$}} \\
\hline & & & & & \\
\hline & & & & & \\
\hline \multicolumn{6}{|c|}{ ANOVA } \\
\hline Model & $\begin{array}{l}\text { Sum of } \\
\text { Squares }\end{array}$ & df & Mean Square & $\mathrm{F}$ & Sig. \\
\hline 1 Regression & 8965592316 & 11 & 815053846.9 & 10.692 & $0.000^{b}$ \\
\hline Residual & 2134475434 & 28 & 76231265.5 & & \\
\hline Total & 1.11E+10 & 39 & & & \\
\hline
\end{tabular}

a.Dependent variable: GDP per capita \$ PPP (Purchasing Power Parity).

b.Predictors: (Constant), Government, Inflation-CPI, Youth Unemployment, GDP in bn \$ PPP,

Compulsory education-years, GDP growth-latest, Land area sqkm, Population below poverty line,

Transparency ranking

\begin{tabular}{|c|c|c|c|c|c|}
\hline \multicolumn{6}{|c|}{ Coefficients } \\
\hline \multirow{2}{*}{ Model } & \multicolumn{2}{|c|}{ Unstandardized Coefficients } & \multirow{2}{*}{$\begin{array}{c}\begin{array}{c}\text { Standardized } \\
\text { Coefficients }\end{array} \\
\text { Beta }\end{array}$} & \multirow{2}{*}{$t$} & \multirow{2}{*}{ Sig. } \\
\hline & $\begin{array}{l}\text { Sum of } \\
\text { Squares }\end{array}$ & df & & & \\
\hline 1 (Constant) & -34169.906 & 25482.152 & & -1.341 & 0.191 \\
\hline Population (million) & -30.458 & 12.844 & -0.397 & -2.371 & 0.025 \\
\hline Land area sqkm & $-1.03 E-05$ & 0.001 & -0.002 & -0.020 & 0.984 \\
\hline Transparency score & 606.081 & 278.962 & 0.806 & 2.173 & 0.038 \\
\hline Transparency ranking & 92.689 & 125.697 & 0.292 & 0.737 & 0.467 \\
\hline GDP in bn $\$$ PPP & 1.819 & 0.768 & 0.410 & 2.369 & 0.025 \\
\hline GDP growth-latest & 310.803 & 841.979 & 0.039 & 0.369 & 0.715 \\
\hline Inflation CPI & 149.253 & 148.022 & 0.105 & 1.008 & 0.322 \\
\hline Youth unemployment & 127.052 & 133.216 & 0.099 & 0.954 & 0.348 \\
\hline Population below poverty line & -190.181 & 136.125 & -0.198 & -1.397 & 0.173 \\
\hline Compulsory education-years & 1455.099 & 648.655 & 0.268 & 2.125 & 0.043 \\
\hline Government & 3502.059 & 4112.717 & 0.096 & 0.852 & 0.402 \\
\hline a.Dependent variable: GDP p & r capita \$ PPP & & & & \\
\hline
\end{tabular}

On the model summary above $\mathrm{R}$ square closer to 1 means that $80.8 \%$ of the variations on the dependent variable are explained by the variability of the independent variables. $\mathrm{R}$ which is the square root of $\mathrm{R}^{\mathrm{R}}$ shows the correlation between dependent variable and independent variables. 80.8\% means that there is high correlation between dependent and independent variables. ANOVA (Analysis of variance) table above, $\mathrm{F}$ value being positive means that explained variance is greater than unexplained variance. $\mathrm{df}$ (degree of freedom-residual) is 28. That means there are 40 observations in the dataset and 12 variables in the equation $(40-12=28)$. 28 is the number of independent coordinates that can specify the position of the system completely. Significance-p value being lower than 0.001 means that there is statistically highly significant relationship among the variables that is not due to chance. On the coefficient table $t$ values are greater than 2, for population however there is an inverse relationship, GDP in billion PPP, transparency score, and compulsory education years. That means these four independent variables are statistically significant on explaining the variances on dependent variable (GDP per capita). P values on the far right of the same table is supplementing this information that these four independent variables are statistically significant on dependent variables by having values between $(0.025-0.043)$. Population (in an inverse relationship) being the most significant and compulsory education being the least among the four most statistically significant independent variables. Population`s being in inverse relationship is a consequence of mathematical relationship between GDP and population to calculate GDP per capita as population is the denominator on the formula (GDP/population). The higher the population the lower the 
GDP per capita. The other independent variables that are in positive relationship with the dependent variable means that the higher, the transparency score, GDP in billion US dollar and compulsory education years the higher the GDP per capita income. The other 7 independent variables have been weak in explaining the changes in dependent variable i.e. land area, transparency ranking, GDP growth, inflation, youth unemployment, population below poverty line and government for future studies these 7 independent variables will not be used in future GDP per capita analysis however youth unemployment will be replaced by general unemployment percentage. It is expected that the higher the GDP and GDP per capita the lower the percentage of total unemployment in a country. The variables that have a significant effect on the dependent variable have been highlighted by yellow (4). The remaining 7 independent variables have no significant effect on GDP per capita. More explanations will be given in the following pages for further possible research.

\section{RESEARCH LIMITATIONS, FUTURE RESEARCH OPPORTUNITIES AND PRACTICAL IMPLICATIONS FOR COUNTRIES}

GDP per capita is the most widely used measure of living standards, it is also a target indicator for policy driven analysis. However, GDP per capita falls short of accurately measuring people's wellbeing due to income inequalities among people. GDP growth analysis still attract many researchers. There are numerous research papers in this field. The limitation of this paper is that it does not cover all the countries on the Earth (more than 200) it does not even cover all the countries (175) on Corruption Perception Index (CPI) issued by Transparency International Organization. It only covers 40 countries, but these 40 countries make up the $64 \%$ of the World s GDP for the year of 2014 . This study can be extended to cover 175 countries reflected on the CPI index. The study can be repeated over and over every year to see if any of the independent variables whose correlation was not significant became significant. It can be done for a specific continent (i.e. Africa), or for South America Subcontinent countries and the differences can be compared. It can be done for example European Union countries and its results can be compared against South American Continent and Africa countries. Africa as a continent is where the whole humanity has emanated from but it is also the least developed. It requires more research in economic development issues.” What are main hurdles for African future development and what remedies would be available for them?” could be another research subject. There are many parameters affecting GDP per capita of a country, the parameters can be altered too. I.e. instead of using "youth unemployment," "total unemployment" criterion can be used. More education triggers more GDP per capita but is this happening evenly in all economically growing countries or some countries are lagging behind? In this respect Program for International Student Assessment-PISA data can be incorporated into the studies of GDP per capita analysis. In other words is GDP going in the direction of human welfare or is it going in the direction of detriment of human welfare? In some countries GDP increases per capita but only a certain strata of people can benefit from it. Disparity of GDP per capita in masses of population might trigger internal disputes within the country. In that respect GINI index can be brought into the analysis.

The main ingredients of GDP is the return on the means of production, namely land, labor and capital which is a mirror reflection of GDP $=\mathrm{C}+\mathrm{I}+\mathrm{G}+(\mathrm{X}-\mathrm{M})$ as explained above. That means if can employ more workforce there will be more production (decrease in unemployment and equal employment for men and women) and more GDP per capita. So governments should find solutions to unemployment problem and incentivize more women into the production. It is not only the quantity of the work force but also the quality of it. Investment in increasing human skills and knowledge through education and training will lead to the improvement of the performance of the workforce, enabling them to do more complex and more productive tasks; and consequently further enhance the increase of GDP per capita. Return on capital is the other main source of GDP which are interest and profit. So as long as the companies and people make profits-net of inflation effcet, pay taxes and earn real interest on their savings, the GDP per capita will grow higher. And the third ingredient is the rent received on land (here the land also encompasses the immovable property that the people of the country own). As long as people earn rental income above the erosion of purchasing power caused by the inflation, the GDP per capita will increase. So, countries take measures that would affect positively all these three factors. Governments 
should incentivize the corporations and people to invest into new and existing businesses and buy properties. In this respect government should act like a catalyst, keep the interest rates low so that people can borrow and expand their business and increase their expenditures which in turn fuel the economy. Governments should keep the inflation low and at a stable level so that people can earn real income above the erosion caused by the inflation. Governments should keep their budgets in balance so their borrowing propensity is curbed which will lead to lower interest rates in the markets.

\section{CONCLUSION}

Regarding the research question "What are the effects of these variables on GDP per capita?” The answer to the research question is given below:

In the hierarchy of the $\mathrm{t}$ and $\mathrm{P}$ values on table 1 (coefficients part) it is observed that:

- Population has an inverse relationship with the GDP per capita. Other things being equal, the lower the population the higher the GDP per capita.

- GDP as an absolute number has a positive correlation with GDP per capita. The higher GDP the higher the GDP per capita.

- Transparency score has a positive correlation with the GDP, the higher the transparency score the higher the GDP per capita.

- Compulsory education years has a positive correlation with GDP per capita. The higher compulsory education for people the higher the GDP/per capita.

The findings above can have the following implications on practical grounds:

- Governments may still incentivize population growth because population growth leads to the increase of youth population within the total population which means more people can join the workforce provided that their GDP growth rate is above the population increase rate and the governments can erase income inequalities among the growing masses of people. The other aspect of the challenge of population growth is mobilizing female population into the workforce which will help further increase the GDP per capita.

- Governments should take every possible measure to increase their GDP. Incentives to erase regional discrepancies in growth, incentives for small business initiatives, incentives for exporters if there is a negative gap in the foreign trade figures are some examples. Keeping the government budget in balance and borrowing at minimum so that interest rates in the economy are kept stable. Stable interest rates will not fuel inflation in the economy. Sustained production growth with minimum government deficit and a balanced foreign trade will curb inflation pressures in the economy and bring stability which in turn will curb the unemployment.

- Transparency is the magic word for growth, especially for developing countries. Transparency encompasses the accountability of central and local governments. What are the taxes spent for? The governments should have their financial statements audited and published regularly for the public eye. Government officials from top to down should be accountable for their actions. In this sense transparency encompasses open regimes-democracies as well. Transparency encompasses the judiciary system. The courts must be independent. The workload of courts must be balanced. The court procedures should be at minimum. A court case should not continue for years unresolved, judges should not change on the same case. The citizens of the country should believe that if their rights are harmed they can claim their losses in the independent judiciary system. If there is an independent judiciary and a stable economy this will in turn attract more Foreign Direct Investment (FDI) into the country which would fuel further economic growth and increase in GDP per capita.

- Compulsory education is another effective variable on GDP per capita. Increase in compulsory education means more trained and educated workforce will be employed. Educated workforce will enhance higher wages which will in turn positively affect GDP per capita. However, quality education is necessary. In this respect some metrics are incorporated into the system to measure its efficacy. I.e. you might have increased the compulsory education years in a country but if the youth is getting low scores from PISA tests then your increase in compulsory educational years is 
Journal of Global Strategic Management | V. 11 | N. 2 | 2017-December | isma.info | 051-062 | DOI: 10.20460/JGSM.2018.252

not effective. The other challenge is the evenly distribution of education accessibility in all regions of the country. Otherwise the country will experience regional discrepancies and income inequalities among the regions. Another aspect of this challenge is creating of equal education opportunities for male and female youth. Mobilization of female youth through enhanced education into the workforce will further fuel increase in GDP per capita.

APPENDIX: The list of countries in the sample:

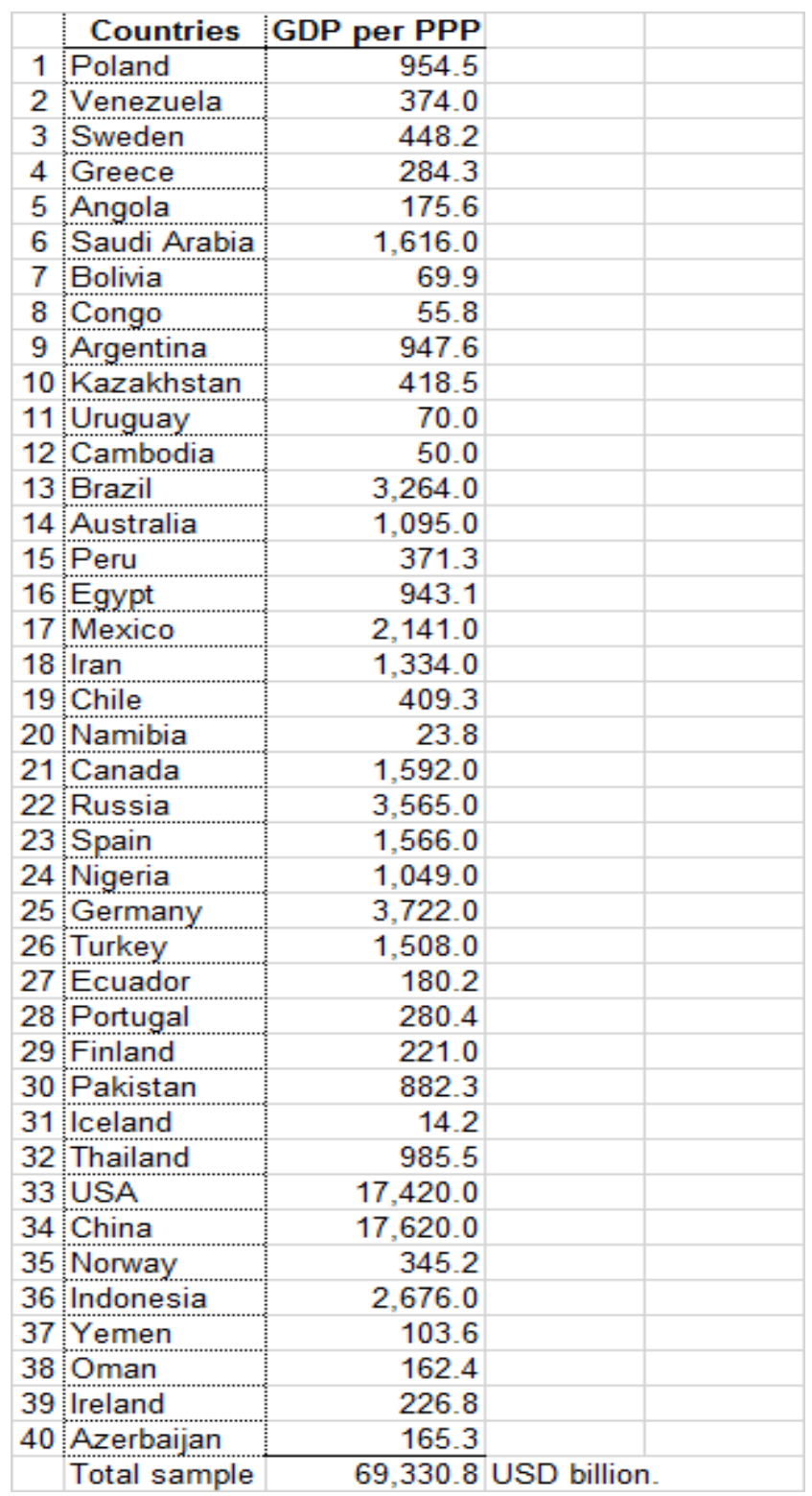




\section{REFERENCES}

Agalega, Evans, Samuel Antwi, 2013, International Business Research; The Impact of Macroeconomic Variables on Gross Domestic Product: Empirical Evidence from Ghana, Vol. 6, No. 5; 2013 ISSN 19139004 E-ISSN 1913-9012, Published by Canadian Center of Science and Education, p.109.

Ajakaiye, Olu, Afeikhena T., Jerome, David Nabena, Olufunke A. Alaba, , Understanding the relationship between growth and employment in Nigeria, Understanding the African Lions- Growth Traps and Opportunities in Six Dominant African Economies, May 2016, p.21.

Alesina, Alberto, Ozler, Sule, Roubini, Nouriel, Swagel, Phillip. 1996, Political instability and economic growth, Journal of Economic Growth 1(2), p:23.

Barry, Craig. September 2014, The relationship between economic growth and population growth, The University of Sheffield, SPERI British Political Economy Brief No. 7, p.3.

Barro, Robert, J., Economic Growth in a Cross Section of Countries, The Quarterly Journal of Economics, Vol. 106, No. 2, May, 1991, Published by: Oxford University Press, Stable

URL: http://www.jstor.org/stable/2937943, p:408

Chughtai, Muhammad Wagas, Muhammad Wagas Malik, Rashid Aftab,( 2015) Impact of Major Economic Variables on Economic Growth of Pakistan, Acta Universitatis Danubius. Economica, Vol $11: 2$

Corruption Watch Annual Report, 2014, http://www.corruptionwatch.org.za/publications/, p:6.

Education at a Glance, How does education affect the economy? http://www.oecd-ilibrary.org/docserver/download/ 9612041ec015.pdf?expires=1452137351\&id=id\&accname=guest\&checksum=59DBA47622F8333F35E1A9F4261BCA01, p:38.

Faria, João, Ricardo, Carniero, Francisco, Galrão (2001), Does high inflation affect growth in the long and short run? Journal of Applied Economics, Vol. IV: 1, May, p:100.

Gokal, Vikesh, Subrina, Hanif,(2004) Relationship Between Inflation And Economic Growth, Working Paper 2004/Economics Department, Reserve Bank of Fiji, 04, December, p.23.

Hahn, Harley(2014), GDP and the Physical Size of a Region, Santa Barbara Independent, Nov.

30, http://www.independent.com/news/2014/nov/30/gdp-and-physical-size-region/

Higgs, Robert(2013), Real Gross Domestic Private Product, 2000-2012, Independent Review, Summer, Vol. 18 Issue 1, p.158.

Hussain, Abid, Hazoor M. Sabir, Mirza Muhammad Kashif(2016), Impact Of Macroeconomic Variables On GDP: Evidence From Pakistan, European Journal of Business and Innovation Research Vol.4, No.3, June, Published by European Centre for Research Training and Development UK, (www.eajournals.org) 38 ISSN 2053-4019 (Print), ISSN 2053-4027 (Online), p.40.

Hussain, Ershad, Mahfuzul Haque,( 2016), Impact of Economic Freedom on the Growth Rate: A Panel Data Analysis, Economies , 4(2), 5; doi:10.3390/economies4020005, p.5.

Jones, Charles, I., Klenow, Peter (2015),Beyond GDP? Welfare across Countries, Stanford University, Version 4, April 20, , http://web.stanford.edu/ chadj/rawls.pdf, p:3.

Kim, Euijune, Hewings, Goeffery, Nam, Kyung-Min (2014), Optimal Urban Population Size: National vs Local Economic Efficiency, Urban Studies, February , p:442.

Luan, Zeyao, Ziyi Zhou(2017), The Relationship Between Annual GDP Growth and Income Inequality: Developed and Undeveloped Countries, Georgia Institute of Technology, ECON 3161 Dr. Shatakshee Dhongde`s class term paper, April, p.4.

Mustapha, Nazar, (2014) The Impact of Corruption on GDP Per Capita, Journal of Eastern European and Central Asian Research Vol 1, No 2, p:4. 
Qureshi, Madeeha Gohar, Eatzaz Ahmed,( 2012) The Inter-linkages between Democracy and Per Capita GDP Growth: A Cross Country Analysis, Pakistan Institute Of Development Economics Islamabad, Working papers,:85, p.24.

Roser, Max, Esteban Ortiz-Ospina (2017), Global Rise of Education, Published online at OurWorldInData.org. Retrieved from: https://ourworldindata.org/global-rise-of-education under the subheading of Is there a causal effect of education on earnings?

Saatci, Esra, Akpinar, Ersin,( 2007) Assessing Poverty and Related Factors in Turkey, Croatian Medical Journal, Oct; 48(5): 628-635, (http://www.ncbi.nlm.nih.gov/pmc/articles/PMC2205969/).

Sachs, Jeffrey, D.( 2012,), Government, Geography, and Growth The True Drivers of Economic Development, Foreign Affairs, September/October,Volume 91, No:5, p.142.

Sinding, Steven W., October (2009), Population, poverty and economic development, Philosophical Transactions B, The Royal Society Publishing,

Smith, Helena,(2016), Greece's economic crisis goes on, like an odyssey without end, The Guardian, 4 January http://www.theguardian.com/business/2016/jan/04/greeces-economic-crisis-goes-on-odyssey-without-end.

Tridico, P. (2013), The impact of the economic crisis on EU labour markets: A comparative perspective. International Labour Review, volume 152: p.176.

Upreti, Parash(2015), Factors Affecting Economic Growth in Developing Countries, Major Themes in Economics, Spring, , p.48.

Vachris, Michelle A(1999)., Thomas, James, International price comparisons based on purchasing power parity. Monthly Labor Review, 00981818, Oct ., Vol. 122, Issue 10, p.3.

World of Work Report( 2014), http://www.ilo.org/wcmsp5/groups/public/---dgreports/---dcomm/documents /publication/wcms_243961.pdf, p:33.

Zhang, Wenbiao, Degang Yang and Jinwei Huo(2016), Studies of the Relationship between City Size and Urban Benefits in China Based on a Panel Data Model, 15 June, Sustainability, p.9.

Websites:

http://ourworldindata.org/data/growth-and-distribution-of-prosperity/world-poverty/

http://www.census.gov/hhes/www/poverty/data/threshld/index.html

https://www.cia.gov/library/publications/the-world-factbook/

http://www.ilo.org/public/english/employment/yen/whatwedo/projects/indicators/2.htm

http://statisticstimes.com/economy/countries-by-gdp-ppp.php

https://tradingeconomics.com/tanzania/corruption-rank

http://www.transparency.org/cpi2014/results 